\title{
Bankruptcy and Postponement of Debt Payments for Large Companies
}

Submitted 14/12/19, $1^{\text {st }}$ revision 09/02/20, $2^{\text {nd }}$ revision 15/03/20, accepted 02/04/20

\begin{abstract}
Agus Nurudin ${ }^{1}$
Abstract:

Purpose: This study aims to elaborate the problem concerning bankruptcy and the postponement of debt payment by arranging it in an article entitled the reconstruction of Law No. 37 of 2004. It also examines the fairness of bankruptcy law in Indonesia in terms of corrective justice and how to reconstruct bankruptcy requirements.

Design/Methodology/Approach: The research method used in this paper is a type of normative juridical analysis with a methodology through statute approach, comparative approach, and conceptual approach.

Findings: Distributive justice emphasizes the principle of proportional similarity and balance between creditors and debtors. In reality, there is an imbalance in the position of creditors and debtors, which can be seen from the easy conditions for bankruptcy of debtors. The conditions referred to are only using a minimum of two creditors and having at least one debt due. With these conditions, the debtor suffers a loss due to a very short minimum period of time, so that the debtor cannot save a penny of his property. This is where the debtor experiences in distributive and corrective injustices.

Practical Implications: For the realization of distributive justice and corrective justice between creditors and debtors, it is important that the bankruptcy law is reconstructed by determining at least 5 creditors and having at least 2 debts due. In addition, it is also important to determine the minimum amount of debt that is due.

Originality/Value: The article examines Law No. 37 of 2004 concerning bankruptcy and postponement of obligations to pay debt in terms of justice, especially distributive justice and corrective justice between creditors and debtors, especially for large companies.
\end{abstract}

Keywords: Debt obligation, corporate, debtors, bankruptcy, reconstruction.

JEL Code: $K 230$.

Paper Type: Research study.

\footnotetext{
${ }^{1}$ Universitas 17 Agustus 1945, Semarang, Indonesia, e-mail: agusnurudin.untagsmg@yahoo.com
} 


\section{Introduction}

The relationship between accounts payable is an issue in business activities, debt is not bad if the company can still repay. However, it will be a problem if the company cannot pay its debts, this is often called insolvency which means it cannot afford to pay (Asyhdie, 2005). The development of the bankruptcy law in Indonesia arises from the influence of 1997 monetary turmoil which has caused enormous difficulties to the national economy, especially the ability of the business world to develop its business (Lindsey, 1998) and to fulfill payment obligations to creditors. This situation in turn has resulted in a chain effect and if it is not immediately resolved it will have a wider impact.

Until now, there have been three laws and regulations relating to bankruptcy arrangements in Indonesia: the Staatsblad (Stb) 1905 Number 217 ammended by Stb 1906 No.348 concerning Bankruptcy Regulation (Brietzke, 2001), the Government Regulation Substitute Act No. 1 of 1998 in conjunction with the Law No. 4 of 1998 that was amended by Law No. 37 of 2004 (Wijayanta, 2014; Wahyudi, 2019). This last regulation stated that debtors who have two or more creditors and do not pay off at least one debt that has been due and can be billed, are declared bankrupt with a court decision, both on their own request and on the request of one or more creditors.

The growing development of the global economy requires bankruptcy law that is able to meet the legal needs of business people in resolving their accounts payable (Nguyen et al., 2019; Rajagukguk, 2009; Sunarmi, 2009; Shubhan, 2019; Shubhan, 2020; Toha and Retnaningsih, 2020; Kliestik et al., 2018; Paseková et al., 2019). Associated with Law No. 37 of 2004 concerning Bankruptcy, there are needs to be a new breakthrough to reconstruct the bankruptcy law so as not to torment the debtors, so that certainty, fairness and legal benefit are achieved. This study aims to elaborate further on the problem and arrange it in an article entitled the reconstruction of Law No. 37 of 2004 concerning Bankruptcy and Postponement of Obligations of Debt Payment with the research how is the fairness of bankruptcy law in Indonesia in terms of corrective justice and how to reconstruct bankruptcy requirements.

\section{Research Methods}

The research method used in this paper uses a type of normative juridical research, with a problem approach used through statute approach, comparative approach, and conceptual approach (Marzuki, 2008). Soemitro (2010) stated that the juridical approach is an approach that refers to the applicable laws and regulations, while the normative approach is an approach that is carried out by examining library materials or secondary data on legal principles and case studies, which in other words, are often referred to as library legal research (Soekanto and Mamudji, 2011). The source of legal material used in this study is the source of primary legal material in the form of relevant laws and regulations, secondary legal material in the form of books on law, and non-legal material in the form of books outside the law. 
Related to the method of analysis of legal materials used in this paper using the deductive method, which is based on the basic principles and then presents the object to be studied, from the general principles towards specific principles.

\section{Bankruptcy Law and Corrective Justice}

According to Aristotle, ideal justice is when all elements of society get the same share of all objects in nature. Humans are seen as equal and have equal rights to the ownership of a material (Von Leyden, 1985). In Aristotle's view, justice is divided into two forms, distributive and corrective justice (Englard, 2009). First, distributive justice is justice determined by law makers, the distribution includes services, rights, and goodness for community members according to the principle of proportional equality. This justice also focuses on distribution, honorarium, wealth, and other goods that can be obtained in the community.

Leaving aside the proof mathematically, it is clear that what is in Aristotle's thought is the distribution of wealth and other valuables based on the prevailing values among citizens. Fair distribution may be a distribution that is in accordance with its good value, namely its value to society (Faiz, 2009). Second, corrective justice is guarantees, supervises, and maintains distribution, and against illegal attacks. The corrective function of justice is principally governed by a judge and stabilizes the status quo by returning the property of the victim concerned or by compensating for his lost property (Muslehuddin, 1991).

The concept of justice, even the concept of certainty and truth will always evolve. Therefore, justice must be able to engage in circular interactions with the development of other sciences, including theology, ideology and technology (Grant, 1991; Aronowitz, 1988; Hess, 1995). Aristotle developed the concept of justice to be intellectual-rational (Weinrib, 1989). Finally, justice is linked to the institutions and collectivities of human life. Changes in the concept of justice from time to time are more common in the operational plane, while the nature is always static and political. From the concept of change and by holding on to the concept of rights then differentiation of types of justice is developed (Anshori, 2018).

The principle of justice that can be accepted by the whole community will be the principle of justice is the incarnation of an agreement that binds and invites a sign of commitment to preserve the principle of justice. Thus, one then considers the psychological costs that must be borne in fulfilling the compensation agreement for binding social and individual movements (Rousseau, 1995). The issue of justice arises when different individuals experience conflict over their interests, so the principles of justice must be able to appear as decision makers and final determinants of disputes over justice (Anshori, 2018).

The existence of the current Bankruptcy Act if analyzed by Aristotelian justice theory can be said to not fulfilling the principle of distributive and corrective justice. 
Associated with the theory of distributive justice, it appears that lawmakers have not provided justice to debtors. The debtor as the bankrupt party is very disadvantaged, as the saying has fallen by the stairs. This distributive justice has not been fulfilled because the legislators make the conditions used to bankrupt the debtor very easy, that is, only using a minimum of two creditors, having at least one debt that is due. Not only that, justice has also not been seen in the absence of a minimum debt limit that the debtor has for filing bankruptcy. In addition, the minimum period of time is also very short, so that the debtor cannot save a cent of his property will give the debtor injustice.

The minimum requirements to be declared bankrupt and the lack of provisions for the minimum amount of collectible debt has an extraordinary impact that all creditors want to recover their debts. This condition has a negative impact on economic development, especially macroeconomics of large companies. It is like a bank that if a large number of customers withdraw money also in a rush can result in bank bankruptcy. Likewise, for large businesses, if most creditors tend to collect debts, it will result in the bankruptcy of large companies. What is happening now is that the conditions for bankruptcy are too easy. Indeed, both creditors and debtors alike need each other. The debtor needs a creditor, and vice versa the creditor needs a debtor, so it should be properly guarded the balance of relations between the creditor and the debtor which Aristotle calls the principle of proportionality.

Furthermore, corrective justice according to Aristotle has also not been seen in Article Law No. 37 of 2004, because there is no consideration from lawmakers for the continuity of business even in the future of the debtor concerned. If distributive and corrective justice is to be fulfilled, then it is time for Law No. 37 of 2004 to be reconstructed. According to Steele (1999), bankruptcy law must contain three principles:

First, the main role of bankruptcy in modern economics is to promote corporate reorganization (Steele, 1999). The law must provide sufficient time, enough for the company to make improvements to the company (Adjie, 2018).

Second, although it is not known that universally applicable bankruptcy law and bankruptcy provisions have evolved over time as changes in political balance between actors, structural transformation of the economy and developments in the history of society, every bankruptcy law aims to balance several objectives including protecting rights creditors and avoid premature liquidation.

Third, bankruptcy law should not only pay attention to creditors and debtors, but more important is to pay attention to the interests of stakeholders in this regard the most important thing is workers. Bankruptcy provisions have indeed granted special privileges for paying salaries owed. In addition, it also needs to be seen whether bankruptcy has a broad impact on consumers or causes a bad economic dislocation. In short, bankruptcy is ultimum remedium, a last resort. 


\section{Reconstruction of Bankruptcy Requirements and Delaying Obligations}

Law No. 37 of 2004 concerning Bankruptcy Laws and Delaying Obligations of Debt Payment translates debt as an obligation that must be paid or can be paid in the amount of money, whether in Indonesian currency or foreign currency, either directly or in the future, arising from the debt agreement or based on the provisions stipulated in the law and which must be paid by the debtor and if not paid give the creditor the right to claim it from the debtor's assets. The regulation of the definition of debt is regulated in the provisions of Law No. 37 of 2004 concerning Bankruptcy Law and Delay of Obligation to Pay Debt because in the provisions of the bankruptcy law that previously did not have provisions governing the interpretation of this debt.

The second requirement for bankruptcy is that one of the debts is due and must be paid. This means that debt is a debt whose payment period has been determined in the debt agreement. Debt that has matured as determined in this debt agreement is the debt that should be paid. The requirements for bankruptcy have been explicitly regulated in Article 1 of Law No. 37 of 2004 concerning Bankruptcy Law and Delay of Obligation to Pay Debt. According to the provisions of this article, the conditions for bankruptcy do not depend on whether the debtor is able to repay his debts but depends on whether the debtor has tried to pay the debt that is due to be paid and also depends on whether he has more than a creditor (Wijayanta, 2004). The findings argue that there is a requirement that one debt has matured and must be paid or must be changed by adding a minimum of two debts that have matured. Thus, the bankruptcy application has considered the business of a debtor to repay debt.

The last requirement to be bankrupt to the Commercial Court is that the debtor has a minimum of two or more creditors (Syahdeni, 2002). Creditors are people who have a debt bill based on a debt agreement or the provisions of the law and their debts can be prosecuted in court. In order for justice to be achieved, the author proposes that a minimum of creditors must be 5 or more, because problems can arise when other creditors who are not bankrupt applicants and their bills have matured or have not yet matured do not intend to take legal action. In addition, it is important to emphasize the size of the debt which in the Bankruptcy Law is stated explicitly, should be at least Rp. 5 billion. This is so that there is a balance of creditors and debtors that also means maintaining the continuity of the mobility of human resources and business resources, resulting in capital and wealth turnover that increases from time to time in the national economy.

Bankruptcy always causes long consequences for creditors and stakeholders of the company, especially company employees because after all the termination of employment will bring unfavorable implications for the company. More broadly the bankruptcy of the company will have an unfavorable influence on the national economy, while many companies are currently facing the threat of bankruptcy applications at the Commercial Court because of the difficulty of paying the company's debt to its creditors. 
The initial concept of establishing provisions on bankruptcy conditions, both the provisions on bankruptcy conditions as stipulated in the Law, are only based on unwillingness in paying debts in accordance with the debt agreement made. The debtor's bankruptcy does not consider the debtor's ability to pay the debt. This concept is indeed different from the concept of bankruptcy in common law systems. In this legal system the concept of bankruptcy is always related to the inability of the debtor to pay his debt. As the definition of bankruptcy states that bankruptcy is the state or condition of one who is unable to pay his debts as they are, or become due (Black, 1974).

Law No. 37 of 2004 concerning Bankruptcy Laws and Delay of Debt Payment Obligations does not stipulate what the minimum requirements are. Provisions like this should be regulated in the Law, because the absence of this arrangement would be very detrimental to the debtor. Debtors whose debts are small compared to the assets they have and this debtor should be able to pay the debt, because there are no provisions regarding the minimum amount of debt that can be bankrupt to the provider. According to the Law, regardless of the amount of debt if there are conditions according to Article 1 paragraph (1), the debtor can be bankrupt to the court. Creditors with a relatively small amount of debt demands (small) can file a bankruptcy application to a court against debtors who are actually able to pay their debts and have far-flung multiple assets compared to debts that must be utilized.

As a comparison of the requirements for filing bankruptcy applications, the authors submit a comparison of regulations regarding the filing requirements for bankruptcy in several countries. The Malaysian state has determined that the requirement to be able to submit a bankruptcy application to a court is that the debtor is unable to pay the debt to the creditor. The debtor's debt amount must be at least 50,000 Malaysian Ringgit. The United Kingdom regulates the minimum amount of debts to be able to submit a bankruptcy application is $£ 5,000$. In August 2014, the Government of the United Kingdom requested evidence to review the limits of creditors' applications for bankruptcy filings, which were set at $£ 750$ in 1986. On January 15, 2015, the Government announced that the creditors' application rate was increased from $£ 750$ to $£ 5,000$ from October 1, 2015 .

India set the minimum amount of debt at the level of 1 lakh (100,000 Rupees). Chapter I Article 4 (1) of the Insolvency and Bankruptcy Code, 2016 stated that this part shall apply to matters relating to the insolvency and liquidation of corporate debtors where the minimum amount of the default is one lakh rupees, and that the Central Government may, by notification, specify the minimum amount of default of higher value which shall not be more than one crore rupees. The US, as an example of common law system, requires bankruptcy filing to be carried out by three or more creditors, where each creditor has a debt that can be claimed to the debtor for at least $\$ 14,425$ (Tanaya and Sudiarawan, 2017). Based on the minimum debt ratio with these countries, for the Indonesian context the amount of debtor's debt is a minimum of Rp. 5 billion. 


\section{Conclusion}

Based on an analysis of the theory of justice, especially distributive justice and corrective justice, it can be concluded that, first, the Bankruptcy Act can now be said to not meet the principles of distributive and corrective justice. Associated with the theory of distributive justice, it can be seen that lawmakers have not provided justice to debtors because the conditions used to bankrupt debtors are very easy, that is, only using a minimum of two creditors, having at least one debt that is due. In addition, justice has not been seen yet, with no debtor minimum limit set for bankruptcy filing. In addition, the minimum period of time is also very short, so that the debtor cannot save a penny of his property will have an impact on injustice to the debtor.

Furthermore, corrective justice has also not been seen in Article Law No. 37 of 2004, because there is no consideration from lawmakers for the continuity of business even in the future of the debtor. Distributive and corrective justice need to be fulfilled, and it is time for Law No. 37 of 2004 to be reconstructed. Second, the reconstruction of bankruptcy requirements can be done by adding a minimum of 5 creditors, a minimum of two debts that have matured and providing a minimum debt of debtors such as in Malaysia, Great Britain, India and America. In Indonesia it can be determined with a minimum amount of debt is, for example, Rp. 5 billion. Thus, the bankruptcy application has considered the business of a debtor to repay debt. This reconstruction is intended so that in the future, it is not easy to bankrupt the debtor. Justice should adopt policies related to human relations, in this case for creditors and debtors. It is fair that can be interpreted according to law and also to be interpreted as what is proportional that it meets the principle of decency.

\section{References:}

Adjie, H. 2018. Joint responsibilities of internal shareholders against credit agreements on limited company bankruptcy: Considering provisions of law of LLC. Journal of Legal, Ethical and Regulatory Issues, 21(Special issue).

Anshori, A.G. 2018. Filsafat hukum hibah dan wasiat di Indonesia. UGM Press.

Aronowitz, S. 1988. Science as power: Discourse and ideology in modern society. University of Minnesota Press.

Asyhdie, Z. 2005. Business Law Principles and the Implementation in Indonesia. Jakarta, RajaGrafindo Persada.

Black, H.C. 1974. Black's Law Dictionary. St. Paul, West Publising Co.

Brietzke, P. 2001. Securitisation and bankruptcy in Indonesia: Theme and variations. Global Jurist Topics, 1(1).

Englard, I. 2009. Corrective and Distributive Justice: from Aristotle to modern times. Oxford University Press.

Faiz, P.M. 2009. John Rawls' Theory of Justice. Jurnal Konstitusi, 6(1), 135-149.

Grant, G. 1991. Technology and justice. House of Anansi.

Hess, D.J. 1995. Science and technology in a multicultural world: The cultural politics of facts and artifacts. Columbia University Press.

Kliestik, T., Vrbka, J., Rowland, Z. 2018. Bankruptcy prediction in Visegrad group countries 
using multiple discriminant analysis. Equilibrium. Quarterly Journal of Economics and Economic Policy, 13(3), 569--593. doi: 10.24136/eq.2018.028.

Lindsey, T. 1998. The IMF and Insolvency Law Reform in Indonesia. Bulletin of Indonesian Economic Studies, 34(3), 119-124.

Marzuki, P.M. 2008. Legal Research. Jakarta, Kencana Prenada.

Muslehuddin, M. 1991. Islamic legal philosophy and Orientalist thought: comparative study of Islamic legal systems. Yogyakarta, Tiara Wacana.

Nguyen, T.A.N., Polách, J., Vozňáková, I. 2019. The role of financial literacy in retirement investment choice. Equilibrium. Quarterly Journal of Economics and Economic Policy, 14(4), 569-589. doi: 10.24136/eq.2019.027.

Paseková, M., Kramná, E., Svitáková, B., Dolejšová, M. 2019. Relationship between legislation and accounting errors from the point of view of business representatives in the Czech Republic. Oeconomia Copernicana, 10(1), 193-210. doi: 10.24136/oc.2019.010.

Rajagukguk, E. 2001. Legal Globalization and Technological Progress: Implications for Indonesian Legal Education and Legal Development. Journal of Law, 2(6).

Rousseau, D. 1995. Psychological contracts in organizations: Understanding written and unwritten agreements. Sage publications.

Shubhan, M.H. 2019. Charging director of company with personal bankruptcy for company mismanagement. Jurnal Hukum dan Peradilan, 8(3), 353-370.

Shubhan, M.H. 2020. Legal Protection of Solvent Companies from Bankruptcy Abuse in Indonesian Legal System. Academic Journal of Interdisciplinary Studies, 9(2), 142142.

Soekanto, S., Mamudji, S. 2011. Normative Legal Research A Short Review. Jakarta, Raja Grafindo Persada.

Soemitro, R.H. 2010. Legal Research Methodology. Jakarta, Ghalia Indonesia.Steele, S. 1999. The new law on bankruptcy in Indonesia: towards a modern corporate bankruptcy regime. Melb. UL Rev., 23, 144.

Sunarmi. 2009. Bankruptcy Law. Medan, USU Press.

Syahdeni, S.R. 2002. Bankruptcy Law-Understanding Faillissements Verordening jo. Law Number 4 of 1998. Jakarta, Pustaka Utama Graffiti.

Tanaya, P.E., Sudiarawan, K.A. 2017. As a result of the bankruptcy law of state-owned enterprises after the enactment of law number 17 of 2003 concerning state finances. Journal of Legal Communication, 3(1), 117-126.

Toha, K., Retnaningsih, S. 2020. Legal Policy Granting Status of Fresh Start to the Individual Bankrupt Debtor in Developing the Bankruptcy Law in Indonesia. Academic Journal of Interdisciplinary Studies, 9(2), 157-157.

Von Leyden, W. 1985. Aristotle on equality and justice: His political argument. Springer.

Wahyudi, F. 2019. The quo vadis of banckrupty settlement and pkpu laws on sharia banking. Jurnal Hukum dan Peradilan, 8(1), 1-20.

Weinrib, E.J. 1989. Aristotle's Forms of Justice. Ratio Juris, 2(3), 211-226.

Wijayanta, T. 2014. Study of the Regulations on Bankruptcy According to Law Number 37 of 2004. Mimbar Hukum 26(1), 1-13. 